\title{
Protected to death: systematic exclusion of pregnant women from Ebola virus disease trials
}

\author{
Melba F. Gomes ${ }^{1 *}$, Vânia de la Fuente-Núñez ${ }^{2}$, Abha Saxena ${ }^{3}$ and Annette C. Kuesel ${ }^{4}$ \\ From Global Forum on Bioethics in Research (GFBR)'s "Ethics of Research in Pregnancy" meeting \\ Buenos Aires, Argentina. 03-04 November 2016
}

\begin{abstract}
Background: For 30 years, women have sought equal opportunity to be included in trials so that drugs are equitably studied in women as well as men; regulatory guidelines have changed accordingly. Pregnant women, however, continue to be excluded from trials for non-obstetric conditions, though they have been included for trials of life-threatening diseases because prospects for maternal survival outweighed potential fetal risks. Ebola virus disease is a life-threatening infection without approved treatments or vaccines. Previous Ebola virus (EBOV) outbreak data showed 89-93\% maternal and 100\% fetal/neonatal mortality. Early in the 2013-2016 EBOV epidemic, an expert panel pointed to these high mortality rates and the need to prioritize and preferentially allocate unregistered interventions in favor of pregnant women (and children). Despite these recommendations and multiple ethics committee requests for their inclusion on grounds of justice, equity, and medical need, pregnant women were excluded from all drug and vaccine trials in the affected countries, either without justification or on grounds of potential fetal harm. An opportunity to offer pregnant women the same access to potentially lifesaving interventions as others, and to obtain data to inform their future use, was lost. Once again, pregnant women were denied autonomy and their right to decide.
\end{abstract}

Conclusion: We recommend that, without clear justification for exclusion, pregnant women are included in clinical trials for EBOV and other life-threatening conditions, with lay language on risks and benefits in information documents, so that pregnant women can make their own decision to participate. Their automatic exclusion from trials for other conditions should be questioned.

Keywords: Pregnancy, Exclusion-criteria, Ebola, Ethics, Risk-benefit, Epidemic, Trials, Research

\section{Background}

The 2013-2016 Ebola virus (EBOV) epidemic was estimated to have caused 28,616 confirmed, probable, and suspected cases and 11,310 deaths [1], but the true burden of EBOV may have been higher. The number of cases and deaths exceeded by more than two orders of magnitude those across all 29 previous outbreaks [1-3]. No approved treatments or vaccines were available and a large number of trials were initiated.

\footnotetext{
* Correspondence: gomesm@who.int

${ }^{1}$ World Health Organization, Geneva, Switzerland

Full list of author information is available at the end of the article
}

Inclusion of women in trials submitted for US registration improved after 1993, when new regulatory guidelines required that a representative sample of patients likely to receive a drug be included in clinical studies and data be analyzed to determine gender differences in response [4-8]. The gender guidelines were developed amidst growing concerns that the drug development process did not provide adequate information about the effects of drugs or biological products in women, particularly HIV treatments, and a general consensus that women should have autonomy to determine participation in clinical trials for themselves $[5,8,9]$. Women are now generally included in trials-provided they are not pregnant and commit, as 
necessary, to effective birth control [9]. Exclusion of pregnant women is still usual practice in trials that do not address obstetric conditions, largely due to concern about birth defects after specific drug exposure in utero and the view that high fetal risk without important medical benefits for the mother is not acceptable $[4,9,10]$. Exclusion, therefore, should not apply to women with life-threatening diseases, as illustrated by early HIV/AIDS drug trials which included pregnant women in the earliest phases-before completion of animal-reproduction studies-because any risk to the fetus was balanced by an overwhelming potential benefit (prolonging life) to the mother [11]. The absence of data on general medical conditions in pregnancy means that pregnant women continue to be treated for nonobstetric conditions with drugs which did not undergo rigorous scientific testing in pregnancy, and for which safe and effective therapeutic doses in pregnancy and maternal and fetal risks are largely unknown [8-10, 12, 13]. More pregnant women and their future offspring are therefore exposed to potential harms through off-label use of medications than would be the case with rigorous scientific testing of medications used during pregnancy $[14,15]$.

In this paper, we review the case fatality data for pregnant women and fetuses/neonates from previous outbreaks and the pregnancy-related eligibility criteria of the therapeutic and vaccine studies in EBOV-affected countries. In the absence of registered treatments or vaccines to control this lethal disease, the World Health Organization (WHO) coordinated and supported research to expedite identification of interventions that could control the outbreak and improve future control efforts. Furthermore, WHO supported many of these studies, which therefore required WHO Ethics Review Committee (WHO-ERC) approval [16]. We reflect on how WHO-ERC made decisions regarding the eligibility of pregnant women during the 2013-2016 outbreak and provide an overview of the case fatality data now available to inform research during future outbreaks.

\section{Data on maternal and pregnancy outcomes informing study protocols in the 2013-2016 EBOV epidemic}

Table 1 summarizes published data from EBOV outbreaks on maternal and pregnancy outcomes, Section A for the previous epidemics, Section B for the 2013-6 epidemic. In the 1976 outbreak, the case fatality rate (CFR) in EBOV-infected pregnant women was 89\% (73/82) [17]. Almost half of all EBOV-infected women were pregnant (46\%: 82/177). The high risk in pregnancy was later attributed to the repeated use of needles for vitamin injections in routine antenatal care without sterilization between patients $[17,18]$. In the 1995 outbreak, 15/105 (14\%) EBOV-infected women were pregnant [17]. The CFR for EBOV-infected pregnant women was $93 \%(14 / 15)$ compared with $70 \%(28 / 40)$ for EBOV- infected non-pregnant women and an overall 77.5\% CFR (245/316) [17]. The differences in CFR are not statistically significant.

In aggregate, any EBOV-infected pregnant woman had survived only after spontaneous miscarriage, elective abortion, stillbirth, or with a neonatal death (Table 1 SectionA). All EBOV-infected pregnant women developed vaginal and uterine bleeding and were at high risk for spontaneous abortion and pregnancy-related hemorrhage [19]. In the 1976 outbreak, the rate of spontaneous abortions was $23 \%(19 / 82)$. The remaining pregnancy outcomes were stillbirths or neonatal deaths-no neonate survived longer than 19 days [18]. In 1995, the spontaneous abortion rate was $67 \%(10 / 15)$, with three elective abortions, one premature stillborn, and one live-born, full-term neonate who died at three days [17]; one of the three elective abortions followed an incomplete spontaneous abortion and the woman survived [17]. Four EBOV-infected mother-baby pairs were traced after the 2000-2001 outbreak in Uganda: all mothers and babies had died [20,21].

\section{Clinical trials of potential treatments and vaccines during the 2013-2016 epidemic in Guinea, Liberia, and Sierra Leone}

At the time of this epidemic, there were no approved specific treatments or vaccines for Ebola virus disease (EVD). Clinical management consisted of supportive care, particularly fluid and electrolyte management, correction of coagulopathy, treatment of secondary infections, and management of other complications [19]. Treatments proposed had not undergone clinical trials in EBOV populations or at all [22-24]. Vaccines were in very early development with few having entered Phase I safety and immunogenicity trials [24-29].

Table 2 lists the trials conducted during the 2013-2016 epidemic in Liberia, Guinea, and Sierra Leone and their pregnancy-related eligibility criteria. All drug and vaccine trials excluded pregnant women. Two of three convalescent plasma studies, funded by the European Union, included pregnant women [30]. Pregnant women were granted access to new treatments only within 'Monitored Emergency Use of Unregistered Interventions' (MEURI) [31] protocols implemented by Médecins Sans Frontières (MSF) for MIL77 (three chimeric monoclonal antibodies targeting different epitopes on the surface of EBOV glycoprotein) and favipiravir [16, 31].

\section{WHO ethics review committee considerations}

The WHO-ERC reviewed all protocols for studies supported or sponsored by WHO, four protocols at the request of the Médecins Sans Frontières Ethics Review Board and one for the Rapid Assessment of Potential Interventions \& Drugs for Ebola (RAPIDE) Consortium 
Table 1 Published data on maternal and pregnancy outcomes after EBOV infection

\begin{tabular}{|c|c|c|c|c|c|}
\hline Location (Time) [Reference] & $\begin{array}{l}\text { Number of } \\
\text { pregnant } \\
\text { women }\end{array}$ & $\begin{array}{l}\text { Pregnancy } \\
\text { stage }\end{array}$ & Age & Maternal outcome & Pregnancy outcome \\
\hline \multicolumn{6}{|c|}{ A. Data available from previous epidemics to inform design of studies in the 2013-2016 EVD epidemic } \\
\hline Southern Sudan (1976) [69] & NS & NS & NS & NS & Occasional premature labour \\
\hline \multirow[t]{4}{*}{ Zaire, Yambuku (1976) [18] } & \multirow[t]{4}{*}{82} & \multirow[t]{4}{*}{ NS } & \multirow[t]{4}{*}{ NS } & \multirow[t]{4}{*}{ Died: 73/82 (89\%) } & Spontaneous abortion: \\
\hline & & & & & 18/73 who died \\
\hline & & & & & 1/9 who survived \\
\hline & & & & & $\begin{array}{l}\text { Live births to women who died: } \\
11 \text { ( } 0 \text { surviving beyond } 19 \text { days) }\end{array}$ \\
\hline \multirow[t]{5}{*}{ Zaire, Kikwit (1995) [17] } & \multirow[t]{5}{*}{15} & 1st: 4 (25\%) & $\begin{array}{l}\text { Mean: } \\
32\end{array}$ & Died: 14/15 (93\%) & Spontaneous abortion: \\
\hline & & 2nd: $6(40 \%)$ & \multirow{4}{*}{$\begin{array}{l}\text { Range: } \\
\text { 24-38 }\end{array}$} & & 9/14 who died \\
\hline & & \multirow[t]{3}{*}{ 3rd: 5 (33\%) } & & & 1/1 who survived \\
\hline & & & & & Stillbirth at 32 weeks: 1 \\
\hline & & & & & $\begin{array}{l}\text { Full term live delivery: } 1 \text { (newborn } \\
\text { died } 3 \text { days later, mother died due to } \\
\text { extreme genital bleeding) }\end{array}$ \\
\hline Gulu, Uganda [70] & 1 & 28 weeks & 30 & Discharged alive & Spontaneous abortion \\
\hline DRC, Isiro (2012) [71] & 1 & 7 months & 29 & Died one day after delivery & $\begin{array}{l}\text { Premature delivery on day } 6 \text { of } \\
\text { disease, newborn died at } 8 \text { days }\end{array}$ \\
\hline \multicolumn{6}{|c|}{ B. Data emerging during the 2013-2016 EVD epidemic } \\
\hline DRC, Equateur (July-Oct 2014) [47] & 1 & NS & NS & Died & Died in utero with mother \\
\hline $\begin{array}{l}\text { Liberia, Monrovia (after August } \\
\text { 2014) }[48]\end{array}$ & 1 & Late stage & 31 & Died & Died in utero with mother \\
\hline \multirow[t]{2}{*}{$\begin{array}{l}\text { Liberia, Monrovia (Aug - Oct } \\
\text { 2014) }{ }^{a}[53]\end{array}$} & \multirow[t]{2}{*}{4} & \multirow[t]{2}{*}{ Late 2 nd /3rd } & \multirow[t]{2}{*}{ NS } & \multirow[t]{2}{*}{ Died: 3 (75\%) } & $\begin{array}{l}\text { Miscarriage shortly before maternal } \\
\text { death: } 3\end{array}$ \\
\hline & & & & & Fetus carried to term: 0 \\
\hline $\begin{array}{l}\text { Guinea, Guéckédou (Feb/March } \\
\text { 2014) }{ }^{b} \text { [50] }\end{array}$ & 1 & NS & 16 & Died $^{9}$ & Spontaneous abortion \\
\hline $\begin{array}{l}\text { Guinea, Guéckédou (June 2014) } \\
\text { [51] }\end{array}$ & 2 & 7 months & $20 \mathrm{~s}$ & Survived & Stillbirths \\
\hline $\begin{array}{l}\text { Guinea, Guéckédou (Dec 2014/ } \\
\text { Jan 15) }[52]\end{array}$ & 2 & $\begin{array}{l}4 \text { months; } \\
5 \text { months }\end{array}$ & $40 / 22$ & Survived & Miscarriages \\
\hline Guinea, Conakry (2015) [56] & 1 & $35-36$ weeks & 25 & $\begin{array}{l}\text { Died day of delivery (treated } \\
\text { with favipiravir outside, but as } \\
\text { per JIKI trial procedures) [38] }\end{array}$ & $\begin{array}{l}\text { Live girl, EBOV qRT-PCR positive, } \\
\text { monitored emergency use of ZMapp } \\
\text { on days 2, 5, 8; buffy coat transfusion } \\
\text { from EVD survivor on day } 11\end{array}$ \\
\hline $\begin{array}{l}\text { Sierra Leone, Kailahun (2014- } \\
2015)^{d}[57]\end{array}$ & 1 & 36 weeks & 34 & Survived & $\begin{array}{l}\text { Induced delivery after diagnosis of } \\
\text { intrauterine fetal death }\end{array}$ \\
\hline $\begin{array}{l}\text { Sierra Leone, Kailahun, Kenema } \\
\text { (May/June 2014) [55] }\end{array}$ & 1 & $35^{h}$ & NS & Died $^{\text {h }}$ & Miscarriage \\
\hline Sierra Leone, Bo $(2014 / 2015)^{\mathrm{e}}[58]$ & 1 & 7 months & 20 & Survived & Stillborn fetus \\
\hline \multirow{2}{*}{$\begin{array}{l}\text { Guinea, Sierra Leone, Liberia MSF } \\
\text { Ebola Treatment Centers (2014-- } \\
\text { 2016) [56] }\end{array}$} & \multirow[t]{2}{*}{$54^{f}$} & \multirow{2}{*}{$\begin{array}{l}\text { 2nd/3rd } \\
\text { trimester }\end{array}$} & \multirow[t]{2}{*}{ NS } & \multirow[t]{2}{*}{ NS } & 2nd trimester miscarriages: 35 \\
\hline & & & & & Neonatal death: 1 (after 2 days) \\
\hline
\end{tabular}


Table 1 Published data on maternal and pregnancy outcomes after EBOV infection (Continued)

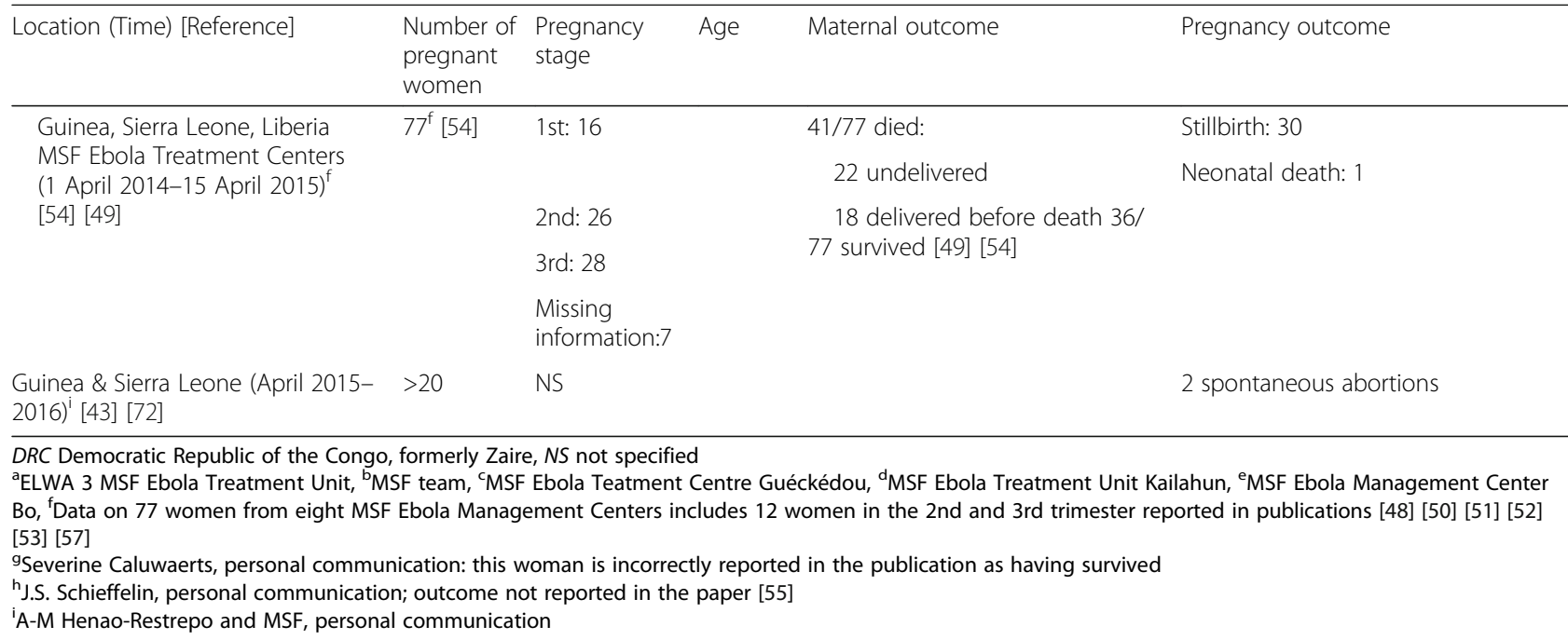

$[16,31,32]$. The WHO-ERC applied the Council for International Organizations of Medical Sciences guidelines [33] and followed the recommendations of a WHO panel of external experts convened to provide ethical guidance on use of unregistered interventions for treatment or prevention of EBOV in a context in which patients were managed with no, or limited, clinical trial data [34]. The WHO panel counselled use of unregistered interventions in the epidemic, conditional upon evidence from laboratory and animal studies. The panel also emphasized that in prioritizing and allocating interventions "children and pregnant women should be considered particularly vulnerable [because of their higher mortality rates]... and given special protection when receiving such interventions" [34]. In the face of the long history of exclusion of pregnant women from clinical trials $[9,15,35-37]$, this recommendation was remarkable and important; the WHO-ERC understood that these groups were to be provided preferential access to interventions. For the WHO-ERC, the virtual certainty of fetal/neonatal loss invalidated exclusion of pregnant women because of risk to the fetus; the high maternal mortality in past Ebola outbreaks favored their inclusion for clinical and ethical reasons. Other ethical considerations dictated that pregnant women should be accorded the same autonomy as non-pregnant adults: pregnant women had a greater interest in and right to decide about their own and their fetus' health than sponsors, researchers, regulators or ethics committees. The WHOERC considered these points equally applicable to vaccine trials in EVD-affected countries that would enroll uninfected participants based on data from Phase I safety and immunogenicity trials and noted that other ethics committees took the same view [31].

By the end of the EBOV epidemic, the WHO-ERC had reviewed 14 protocols for interventional trials as well as two MEURI protocols [16]. These included studies of brincidofovir [32] and favipiravir [38], a study with convalescent plasma [39] and several phases of the rVSV $\Delta \mathrm{G} /$ ZEBOV-GP vaccine [40-43] and the ChAd3-EBO-Z vaccine $[44,45]$. All vaccine protocols, including those in affected countries, excluded pregnant women. The brincidofovir trial excluded pregnant women on the basis of embryotoxicity in animal studies without comment on the relevance of these data for a disease resulting in $100 \%$ human fetal loss; the favipiravir trial could not include pregnant women because the sponsors were unable to get insurance coverage despite strong recommendations for inclusion from the WHO-ERC, MSF Ethics Review Board, and Inserm Institutional Review Board [31]. The WHOERC requested investigators of all treatment and vaccine trials in the affected countries to reconsider exclusion of pregnant women based on benefit-risk assessment, but the requested amendments were not submitted. Therefore, the WHO-ERC faced the difficult dilemma of granting approval for immediate trial start (with potential benefit for the many participants the protocols included) or withholding approval until pregnant women were either included or their exclusion justified. The latter choice would delay trial start in the context of an epidemic for which mortality was high and speed of intervention was essential. Since agreement to include pregnant women would require consensus between numerous parties (including sponsors), which would take time and delay trial start substantially (or possibly indefinitely), WHO-ERC did not make inclusion of pregnant women a prerequisite for WHO-ERC clearance [16]. When interim analysis of the efficacy and safety data in non-pregnant adults in the rVSVAG/ ZEBOV-GP vaccine trial showed benefit, the WHO-ERC (and the Data Safety Monitoring Board) pointed out the high incidence and mortality rates in children and pregnancy and unsuccessfully sought inclusion 
Table 2 Drug and vaccines trials proposed, initiated, or completed during the 2013-2016 Ebola virus disease epidemic in Guinea, Liberia, and Sierra Leone

\begin{tabular}{|c|c|c|c|c|c|c|c|}
\hline $\begin{array}{l}\text { Clinical trial } \\
\text { registry ID }\end{array}$ & $\begin{array}{l}\text { Study } \\
\text { type (Phase) }\end{array}$ & Intervention & $\begin{array}{l}\text { Scientific title [References } \\
\text { to publications] }\end{array}$ & Country & Status & $\begin{array}{l}\text { WHO-ERC } \\
\text { Review } \\
\text { (WHO- } \\
\text { supported) }\end{array}$ & $\begin{array}{l}\text { Pregnant } \\
\text { women } \\
\text { excluded } \\
\text { (test) }{ }^{a, b}\end{array}$ \\
\hline ISRCTN17414946 & $\begin{array}{l}\text { Treatment } \\
\text { (NS) }\end{array}$ & IFN ß-1a & $\begin{array}{l}\text { A pilot study to evaluate the } \\
\text { safety and efficacy of interferon } \\
\text { beta-1a (IFN ß-1a) in the } \\
\text { treatment of patients presenting } \\
\text { with Ebola virus illness }\end{array}$ & Guinea & $\begin{array}{l}<10 \text { patients } \\
\text { enrolled, } \\
\text { results } \\
\text { pending [73] }\end{array}$ & No (No) & Yes (NS) \\
\hline PACTR201411000939962 & $\begin{array}{l}\text { Treatment } \\
\text { (NS) }\end{array}$ & Brincidofovir & $\begin{array}{l}\text { Open-label, non-randomised } \\
\text { single arm trial to investigate } \\
\text { the efficacy of brincidofovir } \\
\text { compared to historic controls } \\
\text { for Ebola virus disease in an } \\
\text { outbreak setting in West Africa } \\
\text { (RAPIDE-BCV) [32] }\end{array}$ & Liberia & Completed & Yes (No) & Yes (Yes) \\
\hline NCT02329054 & $\begin{array}{l}\text { Treatment } \\
(2)\end{array}$ & Favipiravir & $\begin{array}{l}\text { Efficacy of favipiravir in reducing } \\
\text { mortality in individuals with Ebola } \\
\text { Virus Disease in Guinea (JIKI) } \\
\text { [38] [74] }\end{array}$ & Guinea & Completed & Yes (No) & Yes (Yes) \\
\hline NCT02662855 & $\begin{array}{l}\text { Treatment } \\
(2)\end{array}$ & Favipiravir & $\begin{array}{l}\text { Efficacy of favipiravir against severe } \\
\text { Ebola virus disease }\end{array}$ & $\begin{array}{l}\text { Sierra } \\
\text { Leone }\end{array}$ & Completed & No (No) & Yes (NS) \\
\hline ChiCTR-OCN-15007272 & $\begin{array}{l}\text { Treatment } \\
\text { (NS) }\end{array}$ & Favipiravir & $\begin{array}{l}\text { Clinical and virological characteristics } \\
\text { of Ebola Virus Disease patients treated } \\
\text { with favipiravir (T-705) - Sierra Leone, } \\
2014 \text { [75] }\end{array}$ & $\begin{array}{l}\text { Sierra } \\
\text { Leone }\end{array}$ & Completed & No $(\mathrm{No})$ & NS (NS) \\
\hline PACTR201501000997429 & $\begin{array}{l}\text { Treatment } \\
\text { (NS) }\end{array}$ & TKM-130803 & $\begin{array}{l}\text { Open-label, single arm trial to } \\
\text { investigate the efficacy of } \\
\text { TKM-130803 with a concurrent } \\
\text { observational study of Ebola } \\
\text { virus Disease in an outbreak } \\
\text { setting in West Africa (RAPIDE } \\
\text { TKM) [40] [76] }\end{array}$ & $\begin{array}{l}\text { Sierra } \\
\text { Leone }\end{array}$ & Completed & $\mathrm{No}(\mathrm{No})$ & Yes (Yes) \\
\hline NCT02363322 & $\begin{array}{l}\text { Treatment } \\
(1 / 2)\end{array}$ & ZMapp & $\begin{array}{l}\text { A multicenter randomized safety } \\
\text { and efficacy study of putative } \\
\text { investigational therapeutics in the } \\
\text { treatment of patients with known } \\
\text { Ebola infection [77] }\end{array}$ & $\begin{array}{l}\text { Guinea, } \\
\text { Liberia, } \\
\text { Sierra } \\
\text { Leone }\end{array}$ & $\begin{array}{l}\text { Ongoing, } \\
\text { not } \\
\text { recruiting }\end{array}$ & No (No) & Yes (Yes) \\
\hline NCT02333578 & $\begin{array}{l}\text { Treatment } \\
\text { (NS) }\end{array}$ & $\begin{array}{l}\text { Convalescent } \\
\text { plasma }\end{array}$ & $\begin{array}{l}\text { A phase I/II pilot clinical trial to } \\
\text { evaluate the efficacy and safety } \\
\text { of Ebola virus disease (EVD) } \\
\text { convalescent plasma (ECP) for } \\
\text { treatment of EVD }\end{array}$ & Liberia & Recruiting & $\mathrm{No}(\mathrm{No})$ & Yes (Yes) \\
\hline NCT02342171 & $\begin{array}{l}\text { Treatment } \\
(2 / 3)\end{array}$ & $\begin{array}{l}\text { Convalescent } \\
\text { plasma }\end{array}$ & $\begin{array}{l}\text { Emergency evaluation of } \\
\text { convalescent plasma for ebola viral } \\
\text { Disease (EVD) in Guinea [39] } \\
\text { [30] [78] }\end{array}$ & $\begin{array}{l}\text { Guinea } \\
\text { (MSF ETC } \\
\text { Conakry) }\end{array}$ & Completed & Yes (Yes) & No \\
\hline ISRCTN13990511 & $\begin{array}{l}\text { Treatment } \\
(2 / 3)\end{array}$ & $\begin{array}{l}\text { Convalescent } \\
\text { Plasma }\end{array}$ & $\begin{array}{l}\text { Convalescent plasma for early } \\
\text { Ebola virus disease in Sierra } \\
\text { Leone: an open-label, non- } \\
\text { randomized, controlled clinical } \\
\text { trial }\end{array}$ & $\begin{array}{l}\text { Sierra } \\
\text { Leone }\end{array}$ & Completed & No (No) & No \\
\hline $\begin{array}{l}\text { NCT02509494, } \\
\text { PACTR201506001147964 }\end{array}$ & Vaccine (3) & $\begin{array}{l}\text { Ad26.ZEBOV } \\
\text { MVA-BN-Filo }\end{array}$ & $\begin{array}{l}\text { A staged Phase } 3 \text { study, including } \\
\text { a double-blinded controlled stage } \\
\text { to evaluate the safety and } \\
\text { immunogenicity of Ad26.ZEBOV and } \\
\text { MVA-BN-Filo as candidate prophylactic } \\
\text { vaccines for Ebola }\end{array}$ & $\begin{array}{l}\text { Sierra } \\
\text { Leone }\end{array}$ & Recruiting & No (No) & Yes (Yes) \\
\hline
\end{tabular}


Table 2 Drug and vaccines trials proposed, initiated, or completed during the 2013-2016 Ebola virus disease epidemic in Guinea, Liberia, and Sierra Leone (Continued)

\begin{tabular}{|c|c|c|c|c|c|c|c|}
\hline $\begin{array}{l}\text { Clinical trial } \\
\text { registry ID }\end{array}$ & $\begin{array}{l}\text { Study } \\
\text { type (Phase) }\end{array}$ & Intervention & $\begin{array}{l}\text { Scientific title [References } \\
\text { to publications] }\end{array}$ & Country & Status & $\begin{array}{l}\text { WHO-ERC } \\
\text { Review } \\
\text { (WHO- } \\
\text { supported) } \\
\end{array}$ & $\begin{array}{l}\text { Pregnant } \\
\text { women } \\
\text { excluded } \\
\text { (test) }{ }^{a, b}\end{array}$ \\
\hline NCT02575456 & Vaccine (2) & Ad5-EBOV & $\begin{array}{l}\text { A single-center, randomized, blind, } \\
\text { Phase II clinical trial to evaluate the } \\
\text { safety and immunogenicity of the } \\
\text { Adenovirus Type } 5 \text { Vector Based } \\
\text { Ebola Virus Disease Vaccine (Ad5- } \\
\text { EBOV) in healthy adults in Sierra } \\
\text { Leone }\end{array}$ & $\begin{array}{l}\text { Sierra } \\
\text { Leone }\end{array}$ & Completed & No (No) & Yes (Yes) \\
\hline NCT02876328 & Vaccine (2) & $\begin{array}{l}\text { Ad26.ZEBOV, } \\
\text { rVSV } \Delta \mathrm{G} / \\
\text { ZEBOV-GP } \\
\text { MVA-BN-Filo }\end{array}$ & $\begin{array}{l}\text { Partnership for research on Ebola } \\
\text { vaccinations (PREVAC) }\end{array}$ & $\begin{array}{l}\text { Guinea, } \\
\text { Liberia }\end{array}$ & Recruiting & No (No) & Yes (Yes) \\
\hline PACTR201503001057193 & Vaccine (3) & $\begin{array}{l}\text { rVSVDG/ } \\
\text { ZEBOV-GP }\end{array}$ & $\begin{array}{l}\text { A randomized trial to evaluate Ebola } \\
\text { vaccine efficacy and safety in Guinea, } \\
\text { West Africa. Part A: A randomized trial } \\
\text { of ring vaccination to evaluate Ebola } \\
\text { vaccine efficacy and safety in Guinea, } \\
\text { West Africa. Part B: Safety and } \\
\text { immunogenicity of rVSV } \mathrm{G} \text { / ZEBOV- } \\
\text { GP among frontline workers [43] [72] }\end{array}$ & $\begin{array}{l}\text { Guinea, } \\
\text { Sierra } \\
\text { Leone }\end{array}$ & Completed & Yes (Yes) & $\begin{array}{l}\text { Yes (self- } \\
\text { reported, } \\
\text { non- } \\
\text { obligatory } \\
\text { test offered) }\end{array}$ \\
\hline $\begin{array}{l}\text { NCT02378753, } \\
\text { PACTR201502001037220 }\end{array}$ & Vaccine $(2 / 3)$ & $\begin{array}{l}r V S V \Delta G / Z \\
\text { EBOV-GP }\end{array}$ & $\begin{array}{l}\text { rVSVAG-ZEBOV Ebola prevention vaccine } \\
\text { evaluation in Sierra Leone (STRIVE) }\end{array}$ & $\begin{array}{l}\text { Sierra } \\
\text { Leone }\end{array}$ & Completed & No (No) & Yes (Yes) \\
\hline NCT02344407 & Vaccine (2) & $\begin{array}{l}\text { rVSVAG/ } \\
\text { ZEBOV-GP, } \\
\text { ChAd3-EBOZ }\end{array}$ & $\begin{array}{l}\text { Partnership for research on Ebola } \\
\text { vaccines in Liberia (PREVAIL) }\end{array}$ & Liberia & $\begin{array}{l}\text { Active, not } \\
\text { recruiting }\end{array}$ & No (No) & Yes (Yes) \\
\hline
\end{tabular}

Source: WHO International Trial Registry Platform (http://apps.who.int/trialsearch/Default.aspx) and referenced publications

${ }^{a} N S$ not specified, ${ }^{b}$ test-negative pregnancy test required

of the latter, or justification of exclusion. Forty-two pregnant women were denied participation [43]. However, since the trial excluded pregnant women on the basis of self-reported pregnancy status (pregnancy tests were offered, but not obligatory), more than 20 other pregnant women received the vaccine [Henao-Restrepo and MSF, personal communication] [43].

\section{Data from the 2013-2016 EVD epidemic that will inform the design of studies in future EBOV outbreaks}

The 2013-2016 EVD epidemic permitted better estimates of CFRs and factors impacting survival rates and determination of persistence of EBOV in different body fluids.

The CFR across both sexes was 62.9\% (95\% CI: 61.9$64.0 \%$ ) declining from $69.8 \%$ (95\% CI: $58.6-79.2)$ to around 39\% (95\% CI: 25.7-54.3\%) from July 2015 to September 2015. Survival was highest in those under 5 years (75.6\%) and above 75 years $(83.8 \%)$, a pattern similar in all three countries [2]. Both sexes were equally susceptible to infection [46]. In all countries, time from initial symptoms to hospitalization was approximately 0.5 days shorter for women [46]. CFRs were significantly lower for women: $63 \%$ (95\% CI: $61.6-64.4, n=4756)$ versus $67.1 \%$ for men $(95 \%$ CI, 65.8-68.5, $n=4637), p<0.001$; the survival difference was significant after adjustment for age, clinical symptoms, and intervals between onset and hospitalization [46].

Despite the size of the epidemic, and the opportunity, information on pregnancy and pregnancy outcomes was not systematically obtained. Available data are shown in Table 1B; some analyses are ongoing. The maternal CFR estimated from these data is 55\% (44/80) [46-58] excluding approximately 20 pregnant vaccinated women [43]; maternal CFR is not statistically significantly different from the CFR of women overall. All surviving mothers experienced miscarriages or stillbirths [49-51, $57,58]$ and two women died with the fetus in utero [47, 48]. The only surviving baby was born to a woman who had received favipiravir under a MEURI protocol and died. Authorization was given to MSF to treat the newborn, but not the mother, with ZMapp [56] [59]. The reasons for high fetal mortality may be related to EBOV placental preference and consequent high viral load in utero, as samples from amniotic fluid, placenta, and fetuses tested positive for EBOV [52]. Live-born babies appear to have been preterm births and preterm babies normally have a high mortality risk. In EBOV-affected countries where babies are often exclusively breastfed immediately after birth (and there may not be a safe alternative to breastfeeding available), the absence of a surviving 
mother or the inability of an EBOV-infected survivor to breastfeed places a surviving baby at risk of death.

As of 2 February 2016, between 10,000 and 17,000 EBOV survivors were reported compared with 1000 survivors from all previous epidemics combined [2, 60,61]. Compared to blood used for determining cure, clearance of EBOV is delayed (sometimes for months) in immunologically protected fluids/body compartments including semen [62, 63], ocular tissues [64], breastmilk [65], vaginal secretions [66] and the central nervous system [60, 67]. Mother-to-child transmission of EBOV can occur through body fluids in utero, during delivery, contact after birth, and breastmilk, even when the woman is asymptomatic [48]. Among 70 EBOV survivors who conceived post-recovery, 15/68 miscarried and two survivors elected to terminate their pregnancies; four neonates were stillborn (3/4 conceived within two months of discharge of the Ebola Treatment Unit). While still sparse, the data suggest that pregnancies shortly after recovery also increase the risk for poor outcomes [68].

\section{Conclusions}

In this epidemic, a positive diagnosis meant a high probability of mortality; interventions yet to be proven effective provided the best chance of avoiding death. Despite an $89 \%$ maternal CFR and near certain fetal loss in previous outbreaks (i.e. little chance of harming the fetus by administering an experimental intervention), pregnant women were systematically excluded from all drug and vaccine trials. Their automatic disqualification denied pregnant women the potential for benefit given to others. EBOV-infected pregnant women as a class were also harmed because knowledge to protect them (and their fetuses) now lags behind knowledge for other groups. Results from studies that excluded pregnant women cannot be automatically extrapolated to pregnancy. This lack of data specific to pregnancy will negatively impact the health of pregnant women and their access to interventions in the next outbreak.

Each case of EBOV infection during pregnancy in previous outbreaks has resulted in the death of the woman or her fetus; no mother-baby pair has ever survived. Therefore, EBOV infection satisfied two conditions that should have driven inclusion of pregnant women in trials: firstly, EBOV is a life-threatening infection and chance of survival constitutes an important medical benefit. Secondly, with $100 \%$ fetal/neonatal death without intervention, investigational treatment of the mother could not place the fetus at "greater than minimal" added risk. Importantly, by excluding pregnant women, sponsors, investigators, insurance companies, and others influencing protocol provisions violated the autonomy of pregnant women and their right to decide on research participation for themselves, a fundamental ethical principle.

The largest ever EVD epidemic provided ideal conditions to deviate from usual practice for the immediate potential benefit of EBOV-infected pregnant women and the potential benefit of pregnant women in future outbreaks or epidemics. This opportunity was lost. It is time to stop "protecting" pregnant women by excluding them from trials without their consent, and time to insist on rigorous justification of exclusion, thus according pregnant women the same rights and opportunities we offer other adults.

\section{Abbreviations \\ EBOV: Ebola virus; EVD: Ebola virus disease; MEURI: Monitored Emergency Use of Unregistered and Experimental Interventions; WHO: World Health Organization; WHO-ERC: World Health Organization Ethics Review Committee}

\section{Acknowledgements}

We are grateful to $\mathrm{S}$. Caluwaerts for providing us with a pre-publication copy of her book chapter, to J.S. Schieffelin for having provided the maternal outcome of the patient in his article, and to A-M Hanao-Restrepo and MSF for information on vaccinated women in the trial. We also gratefully acknowledge the contribution to the WHO-ERC Ebola-research review of M.R. Balakrishnan, A. Baller, P. Bouvier, K. Fernandez, K. Kennedy, O. Mach, N. Magrini, C. Maure, E. Mumford, B. Ramirez, N. Rollins, M. Senga, J.U. Sommerfeld, S. Suri, and J. Wang-Cavallanti.

\section{Funding}

The publication cost of this article was funded by the Wellcome Trust.

\section{Availability of data and materials}

Not applicable

\section{About this supplement}

This article has been published as part of Reproductive Health Volume 14 Supplement 3, 2017: Proceedings from the Global Forum on Bioethics in Research (GFBR)'s "Ethics of Research in Pregnancy" meeting. The full contents of the supplement are available online at https://reproductivehealth-journal.biomedcentral.com/articles/supplements/volume-14supplement-3.

\section{Authors' contributions}

Authors contributed to WHO-ERC reviews of Ebola-related research as members of the WHO-ERC secretariat (VF-N, AS), the WHO-ERC (ACK) or as WHO-ERC chair (MFG). ACK and VF-N prepared Table 2. ACK and MFG prepared Table 1 and drafted the manuscript, the final version of which was read, reviewed and approved by all authors.

Ethics approval and consent to participate

Not applicable

\section{Consent for publication}

Not applicable

\section{Competing interests}

The authors declare that they have no competing interests.

\section{Publisher's Note}

Springer Nature remains neutral with regard to jurisdictional claims in published maps and institutional affiliations.

\section{Author details}

${ }^{1}$ World Health Organization, Geneva, Switzerland. ${ }^{2}$ Department for Ageing and Life Course, World Health Organization, Geneva, Switzerland.

${ }^{3}$ Department for Information Evidence and Research, World Health 
Organization, Geneva, Switzerland. ${ }^{4}$ UNICEF/UNDP/World Bank/WHO Specia Programme for Research and Training in Tropical Diseases, World Health Organization, Geneva, Switzerland.

Published: 14 December 2017

\section{References}

1. World Health Organization. Ebola situation report. 11 may 2016. 2016. http://apps.who.int/gho/data/view.ebola-sitrep.ebola-summary20160511?lang=en. Accessed 7 May 2017.

2. Garske T, Cori A, Ariyarajah A, Blake IM, Dorigatti I, Eckmanns T, et al. Heterogeneities in the case fatality ratio in the west African Ebola outbreak 20132016. Philos Trans R Soc London B Biol Sci. 2017; doi: 10.1098/rstb.2016.0308.

3. Coltart CEM, Lindsey B, Ghinai I, Johnson AM, Heymann DL. The Ebola outbreak, 2013-2016: old lessons for new epidemics. Philos Trans R Soc B. 2017:372. doi: 10.1098/rstb.2016.0297.

4. U.S. Food and Drug Administration. Center for Drug Evaluation and Research. In: Guideline for the study and evaluation of gender differences in the clinical evaluation of drugs. Washington: Federal Register; 1993. 58(139): 39406-16.

5. Sherman LA, Temple R, Merkatz RB. Women in clinical trials: an FDA perspective. Science (80- ). 1995; doi:10.1126/science.7638593.

6. Merkatz RB, Temple R, Sobel S, Kessler DA. Working group on women in clinical trials. Women in clinical trials of new drugs: a change in Food and Drug Administration policy. N Engl J Med. 1993;9:292-6.

7. Merkatz RB, Junod SW. Historical background of changes in FDA policy on the study and evaluation of drugs in women. Acad Med. 1994;69:703-7.

8. Merkatz RB. Inclusion of women in clinical trials: a historical overview of scientific, ethical, and legal issues. J Obstet Gynocology Neonatal Nurs. 1998;27:78-84.

9. Shields KE, Lyerly AD. Exclusion of pregnant women from industrysponsored clinical trials. Obstet Gynecol. 2013;122:1077-81.

10. Adam MP, Polifka JE, Friedman JM. Evolving knowledge of the teratogenicity of medications in human pregnancy. Am J Med Genet Part C Semin Med Genet. 2011;157:175-82.

11. Merkatz R, Temple R, Sobel S, Feiden K, Kessler DA. Trials WG on W in C. Women in clinical trials of new drugs: a change in Food and Drug Administration policy. N Engl J Med. 1993;329:292-6.

12. Lyerly $A D$, Little MO, Faden RR. Reframing the framework: toward fair inclusion of pregnant women as participants in research. Am J Bioeth. 2011;11:50-2.

13. Cragan JD. Medication use during pregnancy. BMJ. 2014;349 doi: 10.1136/ bmj.g5252.

14. Holmes LB. Human teratogens: Update 2010. Birth Defects Res Part A - Clin Mol Teratol. 2011;91:1-7.

15. Macklin R. Enrolling pregnant women in biomedical research. Lancet. 2010; 375:632-3.

16. Alirol E, Kuesel AC, Guraiib MM, de la Fuente-Núñez V, Saxena A, Gomes MF. Ethics review of studies during public health emergencies - the experience of the WHO ethics review committee during the Ebola virus disease epidemic. BMC Med Ethics. 2017;18

17. Mupapa K, Mukundu W, Bwaka MA, Kipasa M, De Roo A, Kuvula K, et al. Ebola hemorrhagic fever and pregnancy. JID. 1999;179 Suppl 1:22-3.

18. Report of an International Commission. Ebola haemorrhagic fever in Zaire, 1976. Bull World Health Organ. 1978;56:271-93.

19. Jamieson DJ, Uyeki TM, Callaghan WM, Meaney-Delman D, Rasmussen SA. What obstetrician-gynecologists should know about Ebola. Obstet Gynecol. 2014;124:1005-10.

20. Francesconi P, Yoti Z, Declich S, Onek PA, Fabiani M, Olango J, et al. Ebola hemorrhagic fever transmission and risk factors of contacts, Uganda. Emerg Infect Dis. 2003;9:1430-7.

21. Nelson JM, Griese SE, Goodman AB, Peacock G. Live neonates born to mothers with Ebola virus disease: a review of the literature. J Perinatol. 2016;36:411-4.

22. World Health Organization. Potential Ebola therapies and vaccines: interim guidance. 2014. http://apps.who.int/iris/handle/10665/137590. Accessed 15 Dec 2014.

23. Bausch DG, Sprecher AG, Jeffs B, Boumandouki P. Treatment of Marburg and Ebola hemorrhagic fevers: a strategy for testing new drugs and vaccines under outbreak conditions. Antivir Res. 2008;78:150-61.

24. Jones SM, Feldmann H, Ströher U, Geisbert JB, Fernando L, Grolla A, et al. Live attenuated recombinant vaccine protects nonhuman primates against Ebola and Marburg viruses. Nat Med. 2005;11:786-90.
25. Qiu X, Fernando L, Alimonti JB, Melito PL, Feldmann F, Dick D, et al. Mucosal immunization of cynomolgus macaques with the VSVAG/ZEBOVGP vaccine stimulates strong ebola GP-specific immune responses. PLoS One. 2009; doi: 10.1371/journal.pone.0005547.

26. Geisbert TW, Daddario-Dicaprio KM, Lewis MG, Geisbert JB, Grolla A, Leung A, et al. Vesicular stomatitis virus-based ebola vaccine is well-tolerated and protects immunocompromised nonhuman primates. PLoS Pathog. 2008:4:e1000225.

27. Kobinger GP, Feldmann H, Zhi Y, Schumer G, Gao G, Feldmann F, et al. Chimpanzee adenovirus vaccine protects against Zaire Ebola virus. Virology. 2006;346:394-401.

28. Geisbert TW, Bailey M, Hensley L, Asiedu C, Geisbert J, Stanley D, et al. Recombinant adenovirus serotype 26 (Ad26) and Ad35 vaccine vectors bypass immunity to $\mathrm{Ad} 5$ and protect nonhuman primates against ebolavirus challenge. J Virol. 2011;85:4222-33.

29. Martin JE, Sullivan NJ, Enama ME, Gordon IJ, Roederer M, Koup RA, et al. A DNA vaccine for Ebola virus is safe and immunogenic in a phase I clinical trial. Clin Vaccine Immunol. 2006;13:1267-77.

30. van Griensven J, Edwards T, Baize S. Efficacy of convalescent plasma in relation to dose of Ebola virus antibodies. N Engl J Med. 2016; doi: 10.1056/ NEJMC1609116.

31. Schopper D, Ravinetto R, Schwartz L, Kamaara E, Sheel S, Segelid MJ, et al. Research ethics governance in times of Ebola. Public Health Ethics. 2016; doi: 10.1093/phe/phw039.

32. Dunning J, Kennedy SB, Antierens A, Whitehead J, Ciglenecki I, Carson G, et al. Experimental treatment of ebola virus disease with brincidofovir. PLoS One. 2016;11:1-10.

33. Council for International Organizations of Medical Sciences (CIOMS). International ethical guidelines for biomedical research involving human subjects. CIOMS. https://cioms.ch/shop/product/international-ethicalguidelines-for-health-related-research-involvinginvolvinghumans/. Accessed 14 Aug 2014

34. Ethical considerations for use of unregistered interventions for Ebola virus disease - Report of an advisory pannel to WHO. 2014.

35. Mastroianni AC, Faden R, Federman D. Women and Health Research: ethical and legal issues of including women in clinical studies, volume I. Washington, DC: National Academy Press; 1994.

36. Little MO, Lyerly AD, Faden RR. Pregnant women \& medical research: a moral imperative. Bioethica Forum. 2009;2:60-5.

37. Blehar MC, Spong C, Grady C, Goldkind SF, Sahin L, Clayton JA. Enrolling pregnant women: issues in clinical research. Womens Heal Issues. 2013; doi: 10.1016/j.whi.2012.10.003.

38. Sissoko D, Laouenan C, Folkesson E, Lebing AM, Malme K, Manfrin E, et al. Experimental treatment with Favipiravir for Ebola virus disease (the JIKI trial): a historically controlled, single-arm proof-of- concept trial in Guinea. PLoS Med. 2016;13 doi: 10.1371/ journal.pmed.1001967.

39. van Griensven J, Edwards T, de Lamballerie X, Semple MG, Gallian P, Baize S, et al. Evaluation of convalescent plasma for Ebola virus disease in Guinea. N Engl J Med. 2016; doi: 10.1056/NEJMoa1511812.

40. Huttner A, Dayer JA, Yerly S, Combescure C, Auderset F, Desmeules J, et al. The effect of dose on the safety and immunogenicity of the VSV Ebola candidate vaccine: a randomised double-blind, placebo-controlled phase 1/2 trial. Lancet Infect Dis. 2015; https://doi.org/10.1016/S1473-3099(15)00154-1.

41. Agnandji ST, Huttner A, Zinser ME, Njuguna P, Dahlke C, Fernandes JF, et al. Phase 1 trials of rVSV Ebola vaccine in Africa and Europe - preliminary report. N Engl J Med. 2015; doi: 10.1056/NEJMoa1502924.

42. Henao-Restrepo AM, Longini IM, Egger M, Dean NE, Edmunds WJ, Camacho A, et al. Articles efficacy and effectiveness of an rVSV-vectored vaccine expressing Ebola surface glycoprotein : interim results from the Guinea ring vaccination cluster-randomised trial. Lancet. 2015;6736:1-10.

43. Henao-Restrepo AM, Longini IM, Egger M, Dean NE, Edmunds WJ, Camacho A, et al. Efficacy and effectiveness of an rVSV-vectored vaccine in preventing Ebola virus disease: final results from the Guinea ring vaccination, open-label, cluster-randomised trial (Ebola Ça Suffitt). Lancet. 2017; doi: 10.1016/ S0140-6736(16)32621-6.

44. De Santis O, Audran R, Pothin E, Warpelin-Decrausaz L, Vallotton L, Wuerzner $G$, et al. Safety and immunogenicity of a chimpanzee adenovirusvectored Ebola vaccine in healthy adults: a randomised, double-blind, placebo-controlled, dose-finding, phase 1/2a study. Lancet Infect Dis. 2015; doi: 10.1016/ S1473-3099(15)00486-7.

45. Tapia MD, Sow SO, Lyke KE, Haidara FC, Diallo F, Doumbia M, et al. Use of ChAd3-EBO-Z Ebola virus vaccine in Malian and US adults, and boosting of Malian adults with MVA-BN-Filo: a phase 1, single-blind, randomised trial, a phase 
1b, open-label and double-blind, dose-escalation trial, and a nested, randomised, double-bli. Lancet Infect Dis. 2015; doi: 10.1016/ S1473-3099(15)00362-X.

46. Ebola Response Team WHO. Ebola virus disease among male and female persons in West Africa. N Engl J Med. 2016; doi: 10.1056/NEJMc1510305.

47. Maganga GD, Kapetshi J, Berthet N, Kebela Ilunga B, Kabange F, Mbala Kingebeni $\mathrm{P}$, et al. Ebola virus disease in the Democratic Republic of Congo. N Engl J Med. 2014;371:2083-91.

48. Akerlund E, Prescott J, Tampellini L. Shedding of Ebola virus in an asymptomatic pregnant woman. N Engl J Med. 2015;372:2467-9.

49. Caluwaerts S, Lagrou D, Lledo P, Black B, Decroo T, Modet A, et al. Blood, birthing and body fluids: delivering and staying alive in an Ebola management Centre. 2015. https://www.msf.org.uk/sites/uk/files/3._28_ caluwaerts_ebola_ocb_sv_final.pdf. Accessed 10 May 2017.

50. Baize S, Pannetier D, Oestereich L, Rieger T, Koivogui L, Magassouba N, et al. Emergence of Zaire Ebola virus disease in Guinea. N Engl J Med. 2014;371:1418-25.

51. Baggi FM, Taybi A, Kurth A, Van Herp M, Di Caro A, Wölfel R, et al. Management of pregnant women infected with Ebola virus in a treatment centre in Guinea, June 2014. Euro Surveill 2014; 19 (49): pii=20983.

52. Caluwaerts S, Fautsch T, Lagrou D, Moreau M, Camara AM, Günther S, et al. Dilemmas in managing pregnant women with ebola: 2 case reports. Clin Infect Dis. 2016;62:903-5.

53. Chertow DS, Kleine C, Edwards JK, Scaini R, Ruggero G, Sprecher A. Ebola virus disease in West Africa - clinical manifestations and management. $N$ Engl J Med. 2014; doi: 10.1056/NEJMp1413084.

54. Caluwaerts S, Van Hern M, Cuesta JG, Crestani R, Ronsse A, Lagrou D, et al. Pregnancy and Ebola: management and survival of pregnant patients admitted to Médecins Sans Frontières Ebola treatment Centres in the 20142016 West Africa epidemic. In: Schwartz D, Anoko J, Abramowitz S, editors. Pregnant in the time of Ebola. Springer New York: Women and Their Children in the 2013-2015 West African Epidemic; 2017. p. [in press].

55. Schieffelin JS, Shaffer JG, Goba A, Gbakie M, Gire SK, Colubri A, et al. Clinical illness and outcomes in patients with Ebola in Sierra Leone. N Engl J Med. 2014;371:2092-100.

56. Dörnemann J, Burzio C, Ronsse A, Sprecher A, De Clerck H, Van Herp M, et al. First newborn baby to receive experimental therapies survives Ebola virus disease. J Infect Dis. 2017;215:jiw493.

57. Oduyebo T, Pineda D, Lamin M, Leung A, Corbett C, Jamieson DJ. A pregnant patient with Ebola virus disease. Obstet Gynecol. 2015;126:1273-5

58. Bower H, Grass JE, Veltus E, Brault A, Campbell S, Basile AJ, et al. Delivery of an ebola virus-positive stillborn infant in a rural community health center, Sierra Leone, 2015. Am J Trop Med Hyg. 2016;94:417-9.

59. Medicins Sans Frontières. NUBIA first newborn to survive Ebola. 2015. https://msf.exposure.co/nubia. Accessed 1 May 2017.

60. Vetter P, Kaiser L, Schibler M, Ciglenecki I, Bausch DG. Sequelae of Ebola virus disease: the emergency within the emergency. Lancet Infect Dis. 2016;16:e82-91.

61. Fowler R, Mishra S, Chan AK. The crucial importance of long-term follow-up for Ebola virus survivors. Lancet Infect Dis. 2016;16:987-9.

62. Deen GF, Knust B, Broutet N, Sesay FR, Formenty P, Ross C, et al. Ebola RNA persistence in semen of Ebola virus disease survivors - preliminary report. N Engl J Med. 2015; doi: 10.1056/NEJMoa1511410.

63. Sow MS, Etard J-F, Baize S, Magassouba N, Faye O, Msellati P, et al. New evidence of long-lasting persistence of Ebola virus genetic material in semen of survivors. J Infect Dis. 2016; doi: 10.1093/infdis/jiw078.

64. Mattia JG, Vandy MJ, Chang JC, Platt DE, Dierberg K, Bausch DG, et al. Early clinical sequelae of Ebola virus disease in Sierra Leone: a cross-sectional study. Lancet Infect Dis. 2015; doi: 10.1016/S1473-3099(15)00489-2.

65. Bausch DG, Towner JS, Dowell SF, Kaducu F, Lukwiya M, Sanchez A, et al. Assessment of the risk of Ebola virus transmission from bodily fluids and fomites. J Infect Dis. 2007;196(Supp.2):S142-7.

66. Thorson A, Formenty P, Lofthouse C, Broutet N. Systematic review of the literature on viral persistence and sexual transmission from recovered Ebola survivors: evidence and recommendations. BMJ Open. 2016;6:e008859.

67. Howlett P, Brown C, Helderman T, Brooks T, Lisk D, Deen G, et al. Ebola virus disease complicated by late-onset encephalitis and polyarthritis, sierra leone. Emerg Infect Dis. 2016;22:150-2.

68. Fallah MP, Skrip LA, Dahn BT, Nyenswah TG, Flumo H, Glayweon M, et al. Pregnancy outcomes in Liberian women who conceived after recovery from Ebola virus disease. Lancet Glob Heal. 2016:4:e678-9.

69. WHO/International Study Team. Ebola haemorrhagic fever in Sudan, 1976. Bull World Health Organ. 1978;56:247-70.
70. Muehlenbachs A, de la Rosa VO, Bausch DG, Schafer IJ, Paddock CD, Nyakio JP, et al. Ebola virus disease in pregnancy: clinical, Histopathologic, and Immunohistochemical findings. J Infect Dis. 2016;215:64-9.

71. Kratz T, Roddy P, Oloma AT, Jeffs B, Ciruelo DP, De La Rosa O, et al. Ebola virus disease outbreak in Isiro, democratic Republic of the Congo, 2012: signs and symptoms, management and outcomes. PLoS One. 2015;10:1-18.

72. Ebola ca suffit ring vaccination trial consortium. The ring vaccination trial: a novel cluster randomised controlled trial design to evaluate vaccine efficacy and effectiveness during outbreaks, with special reference to Ebola. BMJ. 2015; doi: 10.1136/bmj.h3740.

73. Duraffour S, Malvy D, Sissoko D. How to treat Ebola virus infections? A lesson from the field. Curr Opin Virol. 2017;24:9-15.

74. Mentré F, Taburet A-M, Guedj J, Anglaret X, Keïta S, de Lamballerie X, et al. Dose regimen of favipiravir for Ebola virus disease. Lancet 2015; 15 February 150-151.

75. Bai CQ, Mu JS, Kargbo D, Bin SY, Niu WK, Nie WM, et al. Clinical and Virological characteristics of Ebola virus disease patients treated with Favipiravir (T-705) - Sierra Leone, 2014. Clin Infect Dis. 2016;63:1288-94.

76. Dunning J, Sahr F, Rojek A, Gannon F, Carson G, Idriss B, et al. Experimental treatment of Ebola virus disease with TKM-130803: a single-arm phase 2 clinical trial. PLoS Med. 2016;13:1-19.

77. PREVAIL II Writing Group, Multi-National PREVAIL II Study Team. A randomized, controlled trial of ZMapp for Ebola virus infection. N Engl J Med. 2016;375:1448-56.

78. Edwards T, Semple MG, De Weggheleire A, Claeys Y, De Crop M, Menten J, et al. Design and analysis considerations in the Ebola_Tx trial evaluating convalescent plasma in the treatment of Ebola virus disease in Guinea during the 2014-2015 outbreak. Clin Trials. 2016; doi: 10.1177/ 1740774515621056

\section{Submit your next manuscript to BioMed Central and we will help you at every step:}

- We accept pre-submission inquiries

- Our selector tool helps you to find the most relevant journal

- We provide round the clock customer support

- Convenient online submission

- Thorough peer review

- Inclusion in PubMed and all major indexing services

- Maximum visibility for your research

Submit your manuscript at www.biomedcentral.com/submit
Biomed Central 